\title{
The Role of Investors and Financiers' Support in Globalization of Pakistani Companies
}

Jawaid Ahmed Qureshi' ${ }^{1}$, Muhammad Asif Qureshi², Amanat Ali Jalbani ${ }^{3}$

${ }^{1}$ Associate Professor, Shaheed Zulfikar Ali Bhutto Institute of Science \& Technology (SZABIST)

${ }^{2} \mathrm{PhD}$ scholar at University Utara Malaysia

${ }^{3}$ Professor, Institute of Business Management Karachi

\section{A B S T R A C T}

In the regime of globalization, many companies around the world attempt to globalize their business network beyond domestic boundaries. The stimulus behind that is to nourish, avail opportunities, and earn profits by leveraging the global skills and resources. Such an extension of business can not only benefit them but also to the domestic economies, and overseas economies too in many respects. This study intensively examines the way investors and financers' assist Pakistani companies to expand their business worldwide. When companies flourish their business ventures and even go global, investors feel confident in investing with them. Similarly, financers trust them and finance them at soft/discounted terms. This is a novel study in the matrix of Pakistan. One earlier research on this issue in some other country ascertained only about the role of bank lending in corporate globalization, while this probe also enlarges its scope by probing about the relationship among investors and globally expanding companies.

The research design of this study consists of sequential hybrid research approaches. At the first stage, a qualitative study was conducted to have basic acquaintance about the core theme of the investigation, corporate globalization and the role of investors and banks cum lending agencies to support Pakistani companies. At the second stage, quantitative study was conducted to test the hypotheses. The samples belong to the population of top-five export-oriented sectors in Pakistan since many of their companies have globalized their operations. The findings reveal evidence of trust and support by investors, banks, and lending entities to these companies.

Keywords: Globalization; Corporate Globalization; Bank Lending and Corporate Globalization in Pakistan

\section{INTRODUCTION}

Globalization has resulted in the creation of a global village with a global community. It augments trade liberalization, privatization, and de-regularization. Moreover, there is a globalization of: markets, financial systems, technologies, 
industries/sectors, companies, [production, marketing, supply chains, value chains, and brands i.e. global brands], customers, culture, and even community (i.e. emergence of a global community), (European Commission, 2005; Jeffus, 2003; Qureshi, 2014). The resumption of globalization dates back to human travel, trade, and mass migration from one country to the other, or from one corner to the other of the world. In formal terms, the globalization fostered with the advent of World Trade Organization (WTO) at the end of 1994, or the start of 1995. It has enabled companies around the globe to invest, trade, and transfer technology without any obstructions. Such barricades have been gradually declining among WTO member countries, whereas almost all the countries joined it as its members. Corporate globalization refers to the globalization of companies in terms of trade and/or investment spread over different countries and continents (Hill, 2006; Qureshi and Jalbani, 2013). When companies expand globally, they face regulations of foreign countries, international laws, intensive competition, unique customer preferences, languages, culture, and environmental cum market dynamics. Many of the Pakistani companies in textile, leather, food, and pharmaceutical areas have inaugurated global operations. They possess overseas offices, subsidiaries to facilities. Many of them have got their brands registered overseas. Even Pakistani banks have gone global (Qureshi, 2014). In a bid to stretch their network abroad, they need the support in terms of technical capacity-building and financial capacities from their stakeholders, particularly investors/stockholders and banks cum financial institutions.

This study investigates the increasing role of banks and financial entities in the financial capacity building and providing level playing fields for potential companies' globalization. Moreover, they capitalize on the financial arrangement and comply with the covenants of the financing deals. In return, the lending institutes charge them with interest and regulate the financing contracts with non-price terms like the length of the loan, collateral required to safeguard their financing from the risk of insolvency, amortization schedule, and so on (Li, Qui, and Wan, 2011).

\subsection{Research Problem}

The corporate sector chips in substantially in the economic development of individual countries and the global economy. It is inclusive of public and private limited 
liability companies, operating in manufacturing/production and services sectors, and in terms of size, corporate units consist of small and medium-sized enterprises (SMEs) to large-scale enterprises. Many of them turn big in size, expand, and gradually globalize their operations. Keeping in view the salience of corporatization and corporate globalization, this research ascertains the role, support, and facilities of investors/stockholders, and banks cum financial institutions in Pakistan (as lenders' support is also investigated by Li, Qui, and Wan, 2011) regarding assisting Pakistani companies in accomplishing their objectives of corporate globalization.

\subsection{Research Objectives}

The study probes into two main issues: the support extended by investors and facilities offered by the lending institutions to Pakistan-based globally expanding companies in terms of investment (by investors) and concessionary mark up with convenient terms of the loan, so-called non-price terms (by banks cum financial institutions), which comprise tenor of the loan, instalments and amortization schedule of loan, security/collateral offered against loan, etc.

\subsection{Research Questions}

- The key questions of the study in the context of Pakistani companies include:

- What is the role of banks and financial institutes to support companies for globalization?

- Do banks and financial institutes financially support Pakistani companies (in terms of low interest/price and non-price terms) for their globalization?

- Do banks and financial institutes technically support them for their corporate globalization?

- Are such companies satisfied with such facilities from banks and lending institutes?

- What is the role of investors to support companies for globalization?

\subsection{Research Design}

The research design comprises of sequential hybrid method consisting of qualitative cum quantitative research paradigms. At the first stage, the study tends to be exploratory in the matrix of Pakistan, so it capitalizes qualitative method and then, in the 
wake of clarifying the concepts and the real situations, it turns an explanatory probe by utilizing a survey for quantitative data analysis. Moreover, in terms of time horizon, it's a cross-sectional probe.

\section{Data Collection and Sampling}

The pertinent secondary and tertiary data for this investigation were obtained through literature survey from research articles in journals to other sources of the authentic database, which provided the base for primary data. Regarding qualitative probe, the primary data is obtained through interviews, with the intention to reveal multidimensional knowledge from interviewees. Such probe takes place from distinct populations. One belongs to a sample of top-level international managers of Pakistanbased globally operating companies from top five export-oriented sectors of Pakistan including textile (along with its sub-sectors), food group comprising rice, seafood, and wheat sectors, and leather since many companies from these areas have done the overseas expansion. The other population consists of samples belonging to trade finance managers of top-five Pakistani banks having global branches. They include Habib Bank Limited (HBL), National Bank of Pakistan (NBP), United Bank Limited (UBL), MCB, and Allied Bank Limited (ABL). [Also note that some of these banks have leasing and Mudarba companies as well, which also assist their clients on domestic grounds for their corporate globalization]. The questionnaire for interviews contains open-ended and semi-structured questions. The sample size consists of five reps from each sector, which makes a total of twenty-five samples, and two samples from each bank or total ten samples are selected through convenience procedure (for both groups of populations). Regarding quantitative probe, the primary data is obtained through a wide-scale survey by using questionnaires filled from the international managers of companies in the same sectors (i.e. top-five export sectors), located in different parts of the country. The questionnaire comprises of structured and close-ended questions measured on a 5-point Likert scale. As the focus of the analysis pertains to only private and public limited companies, hence the statistics of Securities and Exchange Commission of Pakistan (SECP) are utilized to obtain reliable figures. The total population of public and private limited companies operative in those five sectors stands 5270 companies (Securities and Exchange Commission of Pakistan, 
2012 as cited by Qureshi, 2014), from which a sample of five plus percent companies is selected randomly, and self-administered questionnaires are mailed to them. From the sampling frame of SECP, samples are drawn through proportionate stratified sampling (to confirm justified representation of each stratum) articulated with systematic random sampling (SRS).

\section{Data Analysis Techniques}

The data analysis techniques include interpretation of interviews and constant comparison method; Reliability Test for assuring reliability of the measurement scale; Correlation Test to measure the strength of linear relationship among concerned variables; Multiple Regression Analysis to find significance of the model and impact of independent variables on dependent variable; and Oneway Analysis of Variance (ANOVA) to learn about equivalence of the means of the five populations.

\subsection{Justification, Originality, and Significance of the Study}

As per the literature search, except the recently undertaken works of the authors of this probe, there is no single study available in Pakistan about corporate Pakistan's move for globalization. The study helps in uncovering the significance of the role of investors/stockholders and banks along with lending agencies to nourish Pakistani corporate sectors in their way toward globalization. This probe can substantially assist to potential Pakistani companies getting dressed to go global, pertinent policy makers, and academia.

\section{LITERATURE REVIEW}

The term corporate globalization bears multiple meanings in different contexts. It refers to the gradual internationalization of companies or corporate global expansion. In addition, some authors refer it as corporate global dominance and global expansion of global companies only (Jeffus, 2003). Global business has been fostered by globalization, which embodies globalization of markets, financial system, technology, standardization, international laws, customers, culture, and community (Anjum, 2011; European Commission, 2005; Jeffus, 2003; Qureshi, 2014; Qureshi and Jalbani, 2015; 2016). Global businesses can trade, invest, and transfer technology and people around the world. 
In addition, the institutions supporting it include the World Trade Organization (WTO), United Nations (UN), World Bank (WB), International Monetary Fund (IMF), and many others. International Labor Organization (ILO), United Nations Conference on Trade and Development (UNCTAD), and Organization for Economic Cooperation and Development (OECD) have developed codes for businesses, particularly global businesses regarding their corporate conduct/governance (Qureshi, 2014), which pose challenges for them, since their execution requires heavy cost. Companies globalize their operations to meet their goals of growth, explore new markets, avail lucrative opportunities and enhance resource base cum learning (Li, Qiu, and Wan, 2011; Jones, 2002). But it is not an easy process, they encounter foreign country/ies) regulations, intensified competition, risks, uncertainty, and volatile markets (Ibid, 2011).

Johnson and Vahlne $(1977 ; 2009)$ explained that many companies resumed their international operations by exporting their products (Johanson, 1966; Nellbeck, 1967; Forsgren and Kinch, 1970; Hornell, Vahlne, and Wiedersheim-Paul, 1973; as cited in Johnson and Vahlne, 2009); and Carlson, 1975), as their sales grew, they hired sales agents in exporting countries, next they installed full-fledged sales subsidiaries overseas, and eventually they developed their facilities overseas to avoid any trade quotas and other tariff or non-tariff barriers to trade. Johnson and Vahlne (2009) chiefly noticed that several studies emphasize the network of relationships, especially with suppliers and buyers. Thus integration of networks in the internationalization process and strategy is widely acknowledged (Bonaccorsi, 1992; Erramilli and Rao, 1990; Ford, 1997; Hakansson, 1982; Hallen, 1986; Majkgard and Sharma, 1998; Martin, Swaminathan, and Mitchell, 1998; Sharma and Johanson, 1987). They argued that global markets are a web of relationships among stakeholders, in which firms develop strategic alliance and invisible partnerships to gain resources (informative, technical, or financial) from others. Thus, a firm getting on international expansion track finds itself insider within the network as well as an outsider. The rapport build up during organizational globalization (i.e. global operations) paves the way for enhanced learning, replication across the network, nourishes trust in the net, and ultimately enhanced commitment.

Evidence has been recorded worldwide that investors/equity holders, banks, and 
lending bodies perceive corporate globalization favorably and support them by investing or loaning them at discounted/concessionary terms (Li, Qiu, and Wan, 2011). Bank lending is the fundamental source of external financing (Ibid, 2011), which seems helpful in corporate globalization too. In international markets, business partners, angel investors, investment banks, and venture capital companies invest in the potentially lucrative ventures of globalizing companies and even born global companies sometimes. Bankers sometimes help them find the right sort of investors. If the project seems to be sound enough, accompanied by well-worked out a business plan and feasibility analysis, designed by veteran global entrepreneurs having vast expertise and experiences, their personal credibility, and proven track record of success, these things pave the way to the attainment of their funding needs. In many cases, even the young graduate's cum entrepreneurs having expertise but no experiences or proven track record of success find angel investors (Bloomberg TV, 2012; Hisrich et al., 2009; Scarborough, 2012). Wellestablished globally operative companies, on the other hand, have the potential to find partners for joint ventures abroad to exploit their expertise, local knowledge, and productive network of relations. In different cases, they avail interest-free finances by offering licensing, franchising, or distribution rights of their products to other parties, and capitalize their resources at their cost and risk. The financing terms include price and non-price terms. The price terms deal with interest rates and the non-pricing terms consist of the covenants of the loan agreement detailing about collateral, length of term finance, relaxation period, amortization schedule, and so forth (Gande, Schenzler, and Senbet, 2009 and Tobin's and Reeb, 2002, as cited in Li, Qiu, and Wan, 2011). Moreover, the covenants of the loan also protect lending institutions in case of borrower default (Castle and Keisman, 1999; John, Lynch, and Puri, 2003 as cited in Li, Qiu, and Wan, 2011), and switching investment in diversified businesses, since the lenders take collateral to mitigate their risks and bind the borrowers by contract to invest in specified ventures only (Boot, Thakor, and Udell, 1991; Diamond, 1993; Rajan and Winton, 1995; Stiglitz and Weiss, 1981 Stulz and Johnson, 1985 as cited in Li, Qiu, and Wan, 2011).

\subsection{Conceptual Framework}

From the above literature, the conceptual framework exhibited in Figure 1 
portrays only two major factors affecting a company's globalization. They consist of investor support, banks, and financial institutions' support as independent variables, and corporate globalization as the dependent variable. They are analyzed further during a survey.

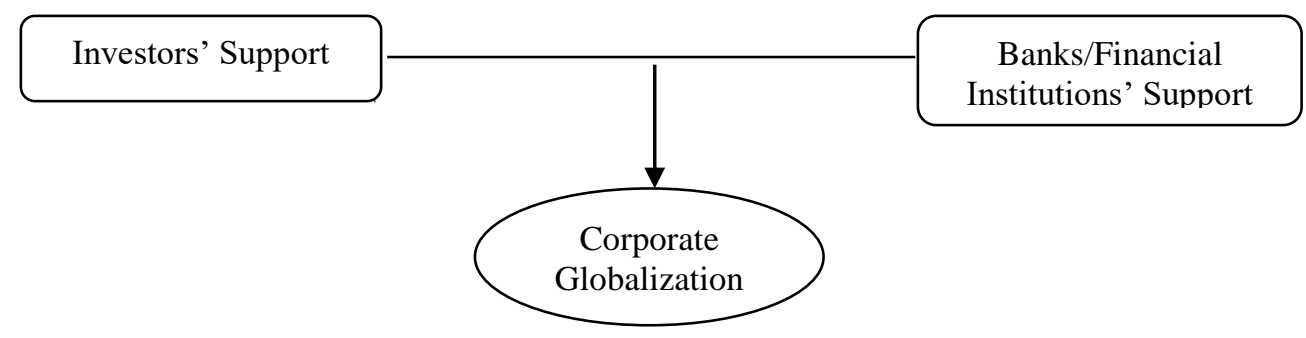

Figure: 1. Conceptual Framework

\subsection{Hypotheses}

From the literature review, the hypotheses under investigation are depicted beneath:

$\mathbf{H}_{1}$ : Investors (stockholders) support (in terms of investment) has a significant and positive association with corporate global globalization/expansion.

$\mathbf{H}_{2}$ : Financers (banks/financial institutions) support (in terms of concessional interest/mark up and non-price terms) has a significant and positive association with corporate global globalization.

$\mathbf{H}_{2.1}$ : Financers (banks/financial institutions) support (in terms of technical assistance) has a significant and positive association with corporate global globalization.

\section{RESEARCH METHODOLOGY}

\subsection{Qualitative Data Analysis}

The interpretation of interviews and their constant comparison from the two distinct groups of samples reveals various facts. The findings of the qualitative data are depicted hereunder:

The officials of Pakistan-based companies that have global operations explain regarding the issue of investors support regarding their move toward corporate globalization that investors/stockholders support them by investing with them for their global ventures. But this calls for a track record of performance, stability in domestic 
operations, sustainable growth and returns over a longer period of time, and rapport built with investors on the basis of trust. The relations with them get a rock solid base when they reveal the financial and non-financial data and performance indicators to them in periodic meetings and annual reports; engage in corporate citizenship or social responsibility acts, and eventually, pass on periodic dividends along with wealth maximization moves through appreciations in their stock values in the open markets. Such assistance is not feasible if their stocks underperform. For leading performers, globalizing operations turn favorable, since the stockholders and potential investors keep waiting for the news about their growth and swift expansion, and they readily invest with them, which enhances their equity value as well. The bottom line is, such sort of trust develops in the wake of historic performance and firm ties with stakeholders. In addition, compliance with the ethical code of corporate conduct attracts creditors inclusive of vendors (who usually offer free of interest trade credit) to such companies, which turns an investment.

Regarding the issue of financial support from the banks/financial institutes by offering loans at low-interest rates and soft non-pricing terms (to globally expanding Pakistani companies), the respondents agreed about that. They support only to the extent of premium customer services by promptly processing the applications for availing export refinancing schemes, letter of credit (LC), and relevant products; they offer discounted markups in domestic lending since they value them by perceiving favorably about their volume of business. Regarding the non-pricing terms of the loans other than interest rates (such as low level of security for the pledge or a lengthy period of maturity), they tend to be very cooperative especially with those customers, so-called their business partners that give them regular and handsome business. They negotiate with banks and financial institutions (FIs) with respect to providing a low level of security for the pledge, a lengthy period of maturity for loans, and other soft terms of loans. There have been incidences when they fully obliged their tested and renowned customers that imported various goods through a letter of credit (LC) and did not provide any mortgage or security to the banks, while their policies tend to be stiff for new and unknown customers. 
When inquired about the technical support of banks/financial institutes (FIs) about corporate globalization, the respondents expressed that when they avail huge financing schemes from them, they appoint one of their top managers of the lending entity to sit on the board of their companies. Those non-exec directors provide expert advice and technical counseling to them regarding their strategic plans and new ventures. This makes them confident and they also get free of charge consultancy toward attainment of their long-run goals and objectives. They strive to build congenial but not disrupting relations with them, and keep on assessing their financial progress in terms of ratio analysis and other performance indicators.

The officials of Pakistan-based companies that have global operations explain about how favorably banks and financial institutions perceive Pakistan-based globally expanding companies by offering loans at low interest rates and soft non-pricing terms, the response of the majority of participants was, "Naturally, yes." Because these companies appear sound enough to stretch their network of operations overseas. Their growth not only benefits the domestic economy but the marvelous growth usually calls for a growing need for financing. The focal point of interest to bankers and professionals of the financial industry is the economic recovery, which is linked up with the growth of various businesses and sectors. This rise of business is reflected in their improved cash flows in terms of accelerated deposits and drawings, interest in saving and investment schemes, or borrowing for further expansion. If an exporter or a globally expanding Pakistani company offers a high business to a bank or finance company, then they tend to lean in front of them by providing them specialized deals, or simply lowered markups. They also support them in non-price terms of the loan, such as convenient mortgage, the extended tenor of the loan, or relaxation in the commencement of installments. The statement expressed by the respondents in aggregate confirmed that bankers and pros of financial entities dealing in loans and advances, offer lenient conditions of financing to them as well as the domestic tycoons and business icons. They facilitate them in nonpricing terms of loan like, convenient mortgage of residential, or commercial, or industrial property, extendable loan tenor that can be rescheduled in some cases, and relaxation in the commencement of installments. Such facilities require the prior consent 
of the regional credit heads and above all, the soundness of the business coupled with financier and borrower's relationships. An interesting example relates to the business of Juria Bazar, Karachi, Pakistan. The local traders of Juria Bazar engaged in import of various commodities and articles perform regular transactions worth millions. Many banks and financing institutions trust them after measuring their business capabilities and track record of performance. So these importers usually do not provide any security or property as collateral to them against opening a letter of credit (LC). However, in individual cases, some of their clients undergo difficulties. If there occur some discrepancies in their documents or when the smaller clients lack collateral.

The banks and financial institutions also support globally expanding Pakistani companies technically, as they offer and insist them the services of a non-executive director to sit on their board to review periodic performance and recommend the rational decisions to accomplish their long-term goals and targets. Such director is an experienced banker and their official who lodges free advisory services and counsel them on strategic decisions. The intention is not to create hitches in their way but rather to chip in technical knowledge. In addition, in the case of financial turbulence, such director can steer them financial solutions and endeavor to reschedule the loan installments or attain max benefits from the lending bank/financial entity.

Upon ascertaining about support to financing exporters and globally expanding companies of Pakistan in foreign countries (provided you have branches there), all the participants agreed that if their existing customers turn the customers of their branches established abroad, it will be an exquisite opportunity to serve them outside of the home. In those foreign chapters, our present Pakistani exporters intending to go global have to develop business relations with those branches by opening accounts and playing various transactions for deposits and withdrawals of funds. Then, they demand their financing need, they could avail as per the statutory framework of the specific foreign country. But our branch officials are business friendly and develop a congenial rapport with their customers.

From the analysis of the structured survey, the findings of the quantitative data are depicted hereunder: 


\begin{tabular}{|l|l|l|l|l|l|l|l|}
\hline \multicolumn{1}{|c|}{ Table 1: Reliability Statistics [Cronbach's Alpha (CA) and N of Items] } \\
\hline CA & N & CA & N & CA & N & CA & N \\
\hline .968 & 15 & .854 & 3 (IS) & .851 & $3($ BFIS) & .743 & $9($ CG) \\
\hline
\end{tabular}

Table 1 exhibited above has the score of measurement scale that is highly reliable for data analysis. The score of <Cronbach Alpha stands $=.968>$ with 15 items and is greater than the benchmark of .70. In addition, it portrays that when a number of items/questions was three, the score stood .956. The individual scores of all the three variables fall between the ranges of .743 to .854 , which means they tend to be highly reliable.

Table 2: Correlation Matrix

\begin{tabular}{|c|c|c|c|c|}
\hline \multicolumn{5}{|c|}{ Table 2: Correlation Matrix } \\
\hline \multirow{3}{*}{ IS } & & IS & BFIS & CG \\
\hline \multirow{3}{*}{ BFIS } & PC & 1 & $.935^{* *}$ & $.816^{* *}$ \\
& Sig. & & .000 & .000 \\
& N & 286 & 286 & 286 \\
\hline \multirow{3}{*}{ CG } & PC & $.935^{* *}$ & 1 & $.812^{* *}$ \\
& Sig. & .000 & & .000 \\
& N & 286 & 286 & 286 \\
& PC & $.816^{* *}$ & $.812^{* *}$ & 1 \\
& Sig. & .000 & .000 & \\
& N & 286 & 286 & 286 \\
\hline
\end{tabular}

Table 2 displays the significant and perfect positive association/correlation among all the variables. The test results portray the greater level of significance at .00 levels, as correlation stand significantly at the benchmark level of 0.01 when performed 2-tailed. The criterion/ dependent variable, corporate globalization (CG) has the correlation of $<\mathrm{r}=.816>$ with the predictor variable investors' support (IS), and the correlation of $<\mathrm{r}=.812>$ with the predictor variable banks/financial institutions' support (BFIS). The independent variables have also perfect positive correlation score with each 
other, which stands $\langle\mathrm{r}=.935>$.

\begin{tabular}{|c|c|c|c|c|c|}
\hline \multicolumn{6}{|c|}{ Table 3: Model Summary and ANOVA (of Multiple Regression Analysis) } \\
\hline R & R Square & $\begin{array}{c}\text { Adjusted R } \\
\text { Square }\end{array}$ & $\begin{array}{c}\text { Std. error of } \\
\text { the Estimate }\end{array}$ & F & Sig. \\
\hline $.848 \mathrm{a}$ & .694 & .692 & .50323 & 153.882 & $.000 \mathrm{a}$ \\
\hline
\end{tabular}

\begin{tabular}{|l|c|c|c|}
\hline Table 4: Coefficients \\
\hline Variables & $\mathrm{B}$ & $\mathrm{t}$ & Sig. \\
\hline Constant & .269 & 2.734 & .001 \\
\hline Investors Support & .435 & 4.991 & .000 \\
\hline Banks/Financial Institutions Support & .417 & 4.953 & .000 \\
\hline
\end{tabular}

a. Dependent Variable: Corporate globalization

The Tables 3 and 4 presented above display R values, ANOVA and Coefficients. In Table 3, the $\mathrm{R}$ values show the coefficient of determination, which is $\langle\mathrm{R}=.848\rangle$, with $\mathrm{R}$ square value of $\langle\mathrm{R} 2=.694>$, and adjusted $\mathrm{R}$ square for $\langle\mathrm{AR} 2=.692>$, which signifies that the predictors explain the criterion variable by $69 \%$. The significance level of the model that is $\langle$ sig. $=.000\rangle$ and the $\mathrm{F}$ value is $\langle\mathrm{F}=153.88\rangle$, which is in the acceptance region. Hence the result shows the overall model fit. In Table 4, the results show that all the independent variables had $t$ scores that are greater than the cut off value of 2 with the significance level that is less than .05 , which means that the predictors appear significant. The individual scores are: constant $\angle \mathrm{B}=.269, \mathrm{t}=2.734$, and sig. $=.001>$, investors support $\angle \mathrm{B}=.435, \mathrm{t}=4.991$, and sig. $=.000>$, and banks/financial institutions support $<\mathrm{B}=.417, \mathrm{t}=4.953$, and sig. $=.000>$. On the basis of the results driven from Correlation and Multiple Regression Analysis, all the hypotheses are accepted.

\begin{tabular}{|l|c|c|c|c|c|}
\hline \multicolumn{7}{|l|}{ Table 5: ANOVA } & Sum of Squares & Df & Mean Square & F & Sig. \\
\hline Between Groups & .047 & 1 & .047 & 1.480 & .062 \\
\hline Within Groups & .127 & 3 & .042 & & \\
\hline Total & .174 & 4 & & & \\
\hline
\end{tabular}

Table 5 shows the value of significance of results, $<$ sig. $=.062>$ means it's insignificant for the estimation of the population. The F statistics is $\langle\mathrm{F}=1.480\rangle$, thus it 
accepts the hypothesis that the means of the populations are not different or they are the same.

\section{DISCUSSION AND CONCLUSION}

Corporate globalization is the extension of a company's operations into global markets through trade and/or investment, and its forms may vary from exports to opening sales offices, branches, or subsidiaries abroad, or doing business through licensing or franchising deals, or establishing manufacturing facilities across borders.

- There is evidence of trust and support (in terms of investment) from investors/stockholders to globalizing companies of Pakistan, who view corporate global expansionary move favorably, which adds their equity value too. Furthermore, vendors also extend credit facilities to them, which turn as an investment without any charges.

- There are evidence of support (in terms of extending loans on soft terms) from the banks/financial institutions to globalizing companies of Pakistan. The exporters and globally expanding Pakistani companies appeared satisfied with the extent of cooperation extended by the banks/financial institutions. They facilitate them in price/interest and non-price terms, which pertain to covenants of the financing consisting of the determinate tenor of the loans, collateral offered, and overall soft terms of loans. Moreover, they intervene by building their technical capacity through free advisory and consultancy services to improve their overall processes. This part of the results matches with that of the study undertaken by Li, Qui, and Wan (2011).

\section{Recommendations (with Covenants and Areas of Further Inquiry)}

The suggestions are submitted hereunder for the consideration of the globally expanding Pakistani companies and banks/financial institutions, and policymakers:

1. Developing sustainable productive relations with existing investors/stockholders by Pakistan-based globally expanding companies: It requires continuous improvement of performance, regular distribution of dividends, disclosing financial and non-financial performance in the interim and annual reports, and 
meeting all the legitimate rights of the investors/stockholders. Additionally, they should worry about availing interest-free trade credit from suppliers, which requires adherence with corporate ethics, meeting due obligations, and exhibition of gentle behavior that attracts creditors and suppliers, because such credit also turns as an investment.

2. Finding investors in overseas markets by Pakistan-based globally expanding companies: It requires looking for joint venture partners that offers both merits and demerits; offering licensing or franchising of business model or technology when applicable; establishing distributors/dealers and sales agents network; finding angel investors through overseas trade partners; searching for venture capital companies or Islamic banks' investment / financing schemes like Mudarba, Musharka, etc. (profit and loss-sharing schemes of partnership with Islamic banks); and going public, especially in the wake of successful operations are several available options.

3. Extension of financing facilities in foreign countries by Pakistani banks having branches abroad: Pakistan head-quartered globally operating banks, so-called top-5 banks inclusive of Habib Bank Limited (HBL), MCB, United Bank Limited (UBL), National Bank Limited (NBP), and Allied Bank Limited (ABL) have branches overseas. They should encourage Pakistani exporters and globally expanding companies that in case they intend to embark operations in a foreign country where they possess a chapter, they can extend the financing facilities and other services to them on a priority basis.

4. Disseminating information about financing policies and facilities of foreign branches from home chapters: The designated officers in their head offices have all the salient acquaintance about the prevailing interest rates, service charges, and prudential requirements in countries where they have a network. Sharing such info will trigger the potential companies to resume negotiations with these banks in their home country so that upon opening up accounts overseas and compliance with the mentioned procedures, they can enjoy credit facilities for their guaranteed overseas expansion. 
This study investigates the move of Pakistani companies toward corporate globalization. However, neither it entertains macro-level generic problems of top-five export sectors in Pakistan (being under investigation), nor it ascertains their individual and micro-level problems, whereas it focuses only on the key aspects of investors/stockholders and banks cum financial institutions support to them. However, in future, a longitudinal survey can be conducted to assess any substantial changes in the domestic matrix.

\section{REFERENCES}

Anjum, M. A. (2011). Illusive and Regressive Globalization: Issues and Challenges for Pakistan Economy. International Journal of Business and Social Sciences, 2(5), 67-76.

Bloomberg TV (2012). Program on Corporate Entrepreneurship. July 1.

Bonaccorsi, A. (1992). On the relationship between firm size and international export intensity. Journal of International Business Studies, 23(4), 605-635. Retrieved from www.jibs.net

Erramilli, M. K., \& Rao, C. P. (1990). Choice of foreign market entry mode by service firms: Role of market knowledge. Management International Review, 30(2), 135150.

European Commission. (2005). Globalization and Internationalization. Retrieved from:

www.phil.muni.cz/.../internationalization-and-globalization-theory.doc

Ford, D. (Ed.). (1997). Understanding business markets. London: The Dryden Press.

Hakansson, H. (Ed.). (1982). International marketing and purchasing of industrial goods: An interaction approach. Cheltenha: Wiley.

Hallen, L. (1986). A comparison of strategic marketing approaches. In P. W. Turnbull \& J.-P. Valla (Eds.), Strategies for international industrial marketing (pp 235-249). London: Croom Helm.

Hill, C. W. L. (2006). Global Business Today (4th ed). Boston: McGraw Hill/Irwin.

Hisrich, R. D., Peter, M. P. \& Shepherd, D. (2009). Entrepreneurship (8th ed), (pp 1-56). New York: McGraw Hill/Irwin Publications.

Jeffus, W. M. (2003). Survey of the Theories of Globalization. wendyjeffus.com/images/Globalization.doc

Johanson, J. \& Vahlne, J.-E. (2009). The Uppsala internationalization process model revisited: From liability of foreignness to liability of outsidership. Journal of International Business Studies, 40, 1411-1431. doi:10.1057/jibs.2009.24

Johanson, J., \& Vahlne, J.-E. (1977). the internationalization process of the firm: A model of knowledge development and increasing foreign market commitments. Journal of International Business Studies, 8(1), 23-32.

Li, S., Qiu, J., \& Wan, C. (2011). Corporate Globalization and Bank Lending. Journal of International Studies, 342(9), 1016-1042. Retrieved from www.jibs.net

Majkgard, A., \& Sharma, D. D. (1998). Client-following and market-seeking in the internationalization of service firms. Journal of Business-to-Business Marketing, 4(3), 1-41.

Martin, X., Swaminathan, A., \& Mitchell, W. (1998). Organizational evolution in the inter- 
organizational environment: Incentives and constraints on an international expansion strategy. Administrative Science Quarterly, 43(3), 566-601.

Qureshi, J. A. \& Jalbani, A. A. (2013). Corporate Globalization and Challenges for Pakistani Companies. Journal of Independent Studies and Research, 11(2), $01-$ 16.

Qureshi, J. A. (2014). Corporate Global Expansion: Challenges and Strategies for Pakistani Companies. Ph.D. Dissertation. Shaheed Zulfiqar Ali Bhutto Institute of Science and Technology, Karachi.

Qureshi, J. A. \& Jalbani, A. A. (2015). Corporatization and Globalization of Pakistani Companies. Journal of Statistics, 22(1).

Qureshi, J. A. \& Jalbani, A. A. (2016). The role of Public Institutions' Support for Globalization of Pakistani Companies. Pakistan Business Review, 2(4), 813828.

Scarborough, N. M. (2012). Effective Small Business Management, an Entrepreneurial Approach (10th ed). New Jersey: Prentice Hall.

Sharma, D. D., \& Johanson, J. (1987). Technical consultancy in internationalization, International Marketing Review, 4(4), 20-29. 